\title{
STORE BRAND PURCHASE INTENTION: EFFECTS OF RISK, QUALITY, FAMILIARITY AND STORE BRAND SHELF SPACE
}

\author{
İnci DURSUN \\ Ebru TÜMER KABADAYI \\ Alev KOCAK ALAN \\ Bülent SEZEN
}

Gebze Institute of Technology, Turkey

\begin{abstract}
The purpose of this research is to investigate the factors effective on consumers' store brand (SB) purchase intention to extend the theoretical and empirical evidence on success of SB strategies. Through this purpose the role of store brand (SB) familiarity, SB shelf space, SB perceived quality and perceived risk were investigated in an integrative model covering direct and indirect effects. Specifically, research focuses on the contribution of familiarity and $S B$ shelf space to $S B$ purchase intention and also their effects on consumers' risk and quality perception of $S B$, which are well known antecedents of $S B$ purchase intention. The results indicate that $S B$ familiarity has a direct and indirect influence on SB proneness; additionally SB shelf space indirectly plays a crucial role on purchase intention. Managerial implications, suggestions for future researches and limitations are provided.
\end{abstract}

\section{INTRODUCTION}

Store brands, also called private brands, own brands, retailer brands, wholesale brands and distributor's own brands, have drawn both academic and managerial attention in parallel with their rapidly growing market share. In recent years more and more retailers carry SBs and these brands have continued to increase in importance particularly in Europe (Liljander et al., 2009) with the prompting of trend toward higher store concentration, the global recession and changing consumer habits (Erdem et al., 2004). It seems that SBs will continue to grow as retailer become more sophisticated marketers continue to expand to new markets (Baltas and Argouslidis, 2007). Also in Turkey, SBs showed a growing trend, especially in food products (Ipsos KMG, 2007). SB has been introduced to Turkish market by Migros in 1957 and afterwards during the second half of 1990's they become a popular strategic tool for retailers. According to AC Nielsen 2006 report, Turkey is one of the fast developing countries for SB market around the world with the high growing percentage of 22 and also market share of approximately 7-8 \% (www.plturkey.org, 2011)

As stated by Richardson et al. (1996), the increase in SB market share partly reflects retailer's recognition that SBs represent an important strategic asset for the firms. SBs benefit consumers by providing a competitive alternative to national brands especially based on the lower prices owing to their lower manufacturing cost, inexpensive packaging, minimal advertising and lower overhead costs (Cunningham et al., 1982; Dick et al., 1995). Additionally, SBs bring on enlarged product assortment and intensified price promotional activity (Pauwels and Srinivasan, 2004) in favor of consumers. SBs also provide some strategic advantages for retailers. They enable retailer to increase consumer traffic and store loyalty (Dick et al., 1995), to enhance retailer margin, and negotiating leverage with national brand manufacturers (Ailawadi et al., 2008). Besides, SBs provide opportunity to differentiate from competitive establishment (Sprott and Shimp, 2004), greater flexibility for establishing prices and promotions (Nogales and Suares, 2005). Moreover, SBs may enable retailers to build a high value offering store image since consumer reports reveal that the range of cheaper priced SB products provided by retailer is important for consumers in deciding what stores offer good value for money (Nielsen, 2008). SBs help retailers to compete profitably in the price-sensitive segment (Corstjens and Lal, 2000). Therefore, SBs have been considered as a critical issue and unique source of competition for retail industry (Quelch and Harding, 1996). Since classic study of Myers (1967) there have been a growing number of SB researches in marketing and retailing literature, not surprisingly following the global emergence of SBs. Especially the indicators of the consumers SB proneness appeared to be 
increasingly important research area for understanding success of SB strategies. For this reason, many factors have been investigated related to SB attitudes, SB proneness, SB purchase intention or SB evaluation. In a similar vein, the main purpose of this study is to provide an increased understanding of SB purchase intention and useful insights for retailers aiming to gain the strategic competitive advantages of carrying SBs. Particularly, the effects of shelf space allocation and SB familiarity on SB purchase intention and perceived quality and risk perception which are the key constructs for generating SB purchase intention have been examined in an integrative relationship network. In accordance with this purpose the paper is organized as follows: In the first section, a brief literature review of SB proneness, risk perception, quality perception, shelf space allocation and familiarity is presented and the research hypotheses are proposed. Then methodology and analysis process are described and results are reported with a brief discussion. Finally, conclusion, managerial implications, suggestion for future research and the limitation of the study are provided.

\section{CONCEPTIONAL FRAMEWORK}

SBs are goods which are owned and merchandised by a particular retailer (Sprott and Shimp, 2004) and sold under the retailers' own name or trade mark through retailers own outlets (Baltas, 1997). These are only brands for which the retailer must take on all responsibility-from development, sourcing and warehousing to merchandising and marketing (Dhar and Hoch, 1997). Improving a well established SB strategy can play a crucial role for retailers since in competition environment; it is difficult to gain more market share for them (Hoch and Banerji, 1993). Understanding consumer SB proneness and purchase intention is at the heart of understanding success essentials for SB strategies.

A considerable amount of literature has been published on factors related to SB proneness. Socioeconomic and personality characteristics (Frank and Boyd, 1965; Myers, 1967; Coe, 1971; Bettman, 1974; Richardson et al.,1996; Baltas and Argouslidis, 2007), shopping orientations such as price consciousness, impulsiveness (Manzur et al. 2009; Kara et al. 2009, Ailawadi et al., 2001; Baltas, 1997), perceived risk (Richardson et al.,1996; Mieres et al., 2006; Batra and Sinha,2000; Liljander et al. 2009), quality/ value perceptions (Richardson et al. 1994, Dick et al., 1995; Anselmsson and Johansson,2009; Liljander et al. 2009, Bao et al., 2011), store related factors such as store image (Semejin et al., 2004; Collins-Dodd and Lindley, 2003; Liljander, Polsa and Riel, 2009; Bao et al., 2011) are predictors that are more frequently investigated. So far, however, there has been no discussion about shelf space allocation effect on consumer SB purchase intention, to the best of our knowledge. Although shelf space management of the store brands was studied from retailer point of view (Gómez and Okazaki, 2009; Nogales and Suarez, 2005) it is also needed to predict the consumer reactions to SB shelf space allocation decisions of retailers.

The current research, where SB refers the brands carrying retailer's name, attempts to analyze direct and indirect role of shelf space on consumer SB purchase intention. SB familiarity is also investigated as one of the key predictive of purchase intention. Quality and risk perceptions are also considered as important antecedents.

\section{Risk}

The most common definition of perceived risk is consumers' subjective expectations of a loss (Sweney et al., 1999) means that any action of a consumer will produce consequences which he can not anticipate with anything approximating certainty, and some of which at least are likely to be unpleasant (Bauer, 1960; Liljander et al., 2009). Risk may manifest itself in a variety of ways such as fear that a product/brand may not possess deliverable attributes, uncertainty regarding product/brand performance or a sense that the purchase of particular brand may invite social disapproval (Dick et al., 1995).

Since perceived risk is an important factor in consumer choices (Bettman, 1973) there has been a large volume of published studies on risk perception (Kaplan et al., 1974; Keller, 2008), its antecedents and consequences. Perceived risk was also examined in SB domain as one of the main influencer. There are empirical evidences suggesting that perceived risk decreases SB proneness (Dick at al., 1995; Richardson et al.,1996; Mieres et al., 2006; Batra and Sinha, 2000; Liljander et al., 2009) since brand purchasing is more likely when the consumer is confident that she/he can obtain satisfactory performance (Baltas, 1997). Similarly, we propose same negative relationship:

H1. Perceived risk of SB usage negatively effects SB purchase intention 


\section{Quality}

Aaker (1991) has declared perceived quality as an important dimension of brand equity and describes it as an intangible overall feeling about a brand that, however, is usually based on underlying dimensions including characteristics of products to which the brand is attached such as reliability and performance. Perceived quality is a very significant determinant of SB success (Sprott and Shimp, 2004) and was found to have a substantial impact on SB purchase intention (Dick et al., 1995; Bao et al., 2011), sometimes more than perceived value of SBs (Richardson et al. 1994). Accordingly, quality of store brand relative to national brands was appeared as one of the six variables that explain the market share of SBs (Dhar and Hoch, 1997). Consistent with these findings it is hypothesized that;

H2. Perceived quality of SB positively effects SB purchase intention.

Literature indicates that store brands suffer from a low-quality image that is probably fostered by widespread use of inexpensive looking packaging and absence of an attractive brand image due to poor communication and positioning strategies (Richardson et al., 1994). Mieres et al. (2006) point out that perceived inferiority of SBs is a source of uncertainty for consumers on the level of satisfaction that they can obtain with the purchase of these brands and therefore it increases the risk associated with its purchase. So it is proposed that;

H3. Perceived quality of SB negatively effects perceived risk of SB usage.

\section{SB Familiarity}

Alba and Hutchinson (1987, p. 411) describe familiarity as the number of product/brand related experiences that have been accumulated by the consumer including direct and indirect experiences such as advertising exposures, interactions with salespersons, word of mouth communications, trial and consumption. Baker et al. (1986) state that familiarity exerts important effects on brand choice by (1) enhancing perceptual identification of a brand, (2) increasing the probability of inclusion in the evoked set, (3) generating positive affect toward the brand, and (4) motivating purchase behavior. There are also some empirical evidences regarding the impact of familiarity in SB domain. For example Dick et al. (1995) found that there is a link between store brand familiarity and proneness probably because greater familiarity serves to increase the experience based understanding that store brand are of better quality. Richardson et al. (1996) reported that store brand familiarity enhance store brand proneness while reducing extrinsic cue reliance, perceived quality variation and perceived risk of using SB.

Given the empirical evidence above and considering that the lack of familiarity contributes to elimination of the brand from consideration set for purchase decisions (Dick et al., 1995) it is proposed that:

H4. SB familiarity positively effects SB purchase intention.

On the other hand, literature shows some support for the link between familiarity and quality (Lin et al., 2009; Mieres et al., 2006). Richardson et al. (1996) address that in the specific case of SB, high familiarity may signal for providing high level of quality. Moreover, familiarity is proposed to have impact on the perceived risk. Given the stereotype of SB as "risky" alternatives familiarity is an important determinant of choice (Baltas, 1997). The relationship between SB familiarity and perceived risk has been subjected to some studies which have mentioned that high familiarity of SB may reduce risk perception of consumer (Mieres et al., 2006; Richardson et al., 1996). In consequence, we suggest that;

H5. SB familiarity negatively effects perceived risk of SB usage.

H6. SB familiarity positively effects perceived quality of SB.

\section{Shelf Space}

Shelf space is a limited resource that must be optimally divided among a diverse range of brands or product categories (Gómez and Okazaki, 2009). Shelf space allocation decisions have received significant attention by marketing researchers (See Amrouche and Zaccour, 2007 for literature review) but the research on the shelf space allocation for store brands is relatively scarce (Gómez and Okazaki 2009; Amrouche and Zaccour, 2007; Nogales and Suarez, 2005).

It is obvious that there are opportunity costs and many factors (e.g per unit profit, demand levels, rivalry) to consider in determining the amount of shelf space (Brown and Lee, 1996) for store brands. 
However, looking of the SB shelf space allocation problem from the consumers' view can be very helpful to establish an effective SB strategy. The current study underlines a consumer perspective that should be taken into consideration while making SB shelf space decision. It is suggested that consumers' perception about the amount of the shelf space allocated to SBs would be directly and indirectly effective on SB purchase intention.

Brown and Lee (1996) indicate that shelf space might be considered as a form of advertising, putting products on the top of consumer minds, and generally suggesting products popularity level. Researchers also suggest that shelf space may also affect demand by reducing consumer search cost. Nogales and Suarez (2005) also state that giving a product category or particular brand more space on the shelf increases its visibility and consequently the probabilities of it being purchased. Thus, it is proposed that:

H7. Perceived amount of shelf space allocated to SB positively effects SB purchase intention.

H8. Perceived amount of shelf space allocated to SB positively effects SB familiarity

Narasimhan and Wilcoz (1998) provide rationale evidence by arguing that consumers usually perceive SB as a lower-quality and more-risky product comparing with other product categories. In our study, amount of shelf space proposed to help retailer to reduce risk perception and increase quality perception of SB by creating a high value brand image. So it is proposed that:

H9. Perceived amount of shelf space allocated to SB negatively effects perceived risk of SB usage.

H10. Perceived amount of shelf space allocated to SB positively effects perceived quality of SB.

\section{Figure 1. Research Model}

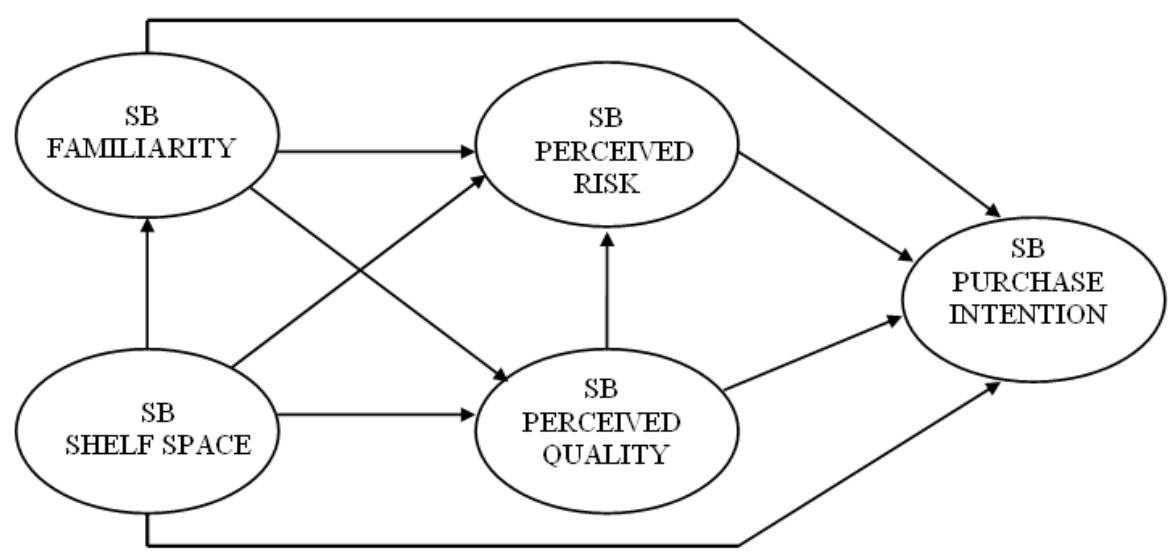

\section{METHODOLOGY}

To test the above hypotheses data was collected from graduate students through a survey. The study included five supermarkets operating in Turkey and four products including food and homecare products. Supermarkets were chosen among major chains which operate countrywide and provide SBs for a variety of grocery products with the motivation for obtaining the variance in SB quality, familiarity and shelf space allocation. Four questionnaires were designed for each supermarket respect to four products: milk, olive oil, napkin and detergent for dish washer. The need for variance in perceived risk, guided the product selection process. Respondents were asked to select the market where they had lastly shopped and randomly given one of the four questionnaires.

Convenience sampling technique was used to select the participants. A total of 200 questionnaires were delivered to graduates students from two universities; one in Istanbul and the other in Kocaeli, Turkey. 173 questionnaires were returned yielding a response rate of $87 \%$.

\section{Measurement}

Consumers' risk and quality perception of SBs, familiarity and purchase intention were measured using three item five point Likert-type scale with anchors of $1=$ strongly disagree and $5=$ strongly agree 
based on validated scales from the literature. Perceived risk was measured by using items adapted from study of Stone and Gronhaug (1993). Scale for measuring quality was drawn from the product quality scale of Yoo et al. (2000). SB familiarity measure was adopted from scale of Kent and Allen (1994) for familiarity manipulation check. The purchase intention scale was adopted following Bruner et al. (2001). Finally, shelf space allocation for SB was measured by asking respondents what was the extent of shelf space allocated for SB products. Measurement items were displayed in Table II.

Questionnaire also included questions regarding demographic factors including gender, age, household size and average household income. Sample characteristics were summarized in Appendix.

\section{Table II Measurement Items}

\begin{tabular}{|c|c|c|c|c|}
\hline & $\begin{array}{c}\text { Standardize d } \\
\text { Estimates }\end{array}$ & $\begin{array}{l}\text { Cronbach's } \\
\text { Alpha }\end{array}$ & CR & AVE \\
\hline SB purchase intention & & 0.69 & 0.70 & 0.53 \\
\hline It is very likely that I will buy store branded....(product) & $.75^{*}$ 水 & & & \\
\hline I will definitely try store branded....(product) & $.71^{* *}$ & & & \\
\hline I have knowledge about store branded ...(product) & $.82^{\text {水 }}$ & & & \\
\hline I am familiar with store branded...(product) & $.55^{\text {㭋 }}$ & & & \\
\hline SB Quality & & 0.92 & 0.92 & 0.80 \\
\hline Store branded..... (product) appeared to be high functional & $.97^{\text {k水 }}$ & & & \\
\hline $\begin{array}{l}\text { All things considered, I think I would be making a mistake if I } \\
\text { bought a store branded ...(product) }\end{array}$ & $.93^{\text {氺 }}$ & & & \\
\hline $\begin{array}{l}\text { I feel that the purchase of a store branded ....... (product) poses } \\
\text { problems for me that I just needed }\end{array}$ & $.89^{* 1 *}$ & & & \\
\hline $\begin{array}{l}\text { The thought of buying a store branded ..... (product) causes me } \\
\text { to be concerned with experiencing some kind of loss.. }\end{array}$ & $.79^{* * 1}$ & & & \\
\hline $\begin{array}{l}\text { Shelf Space } \\
\text { In .... (market) an extensive shelf space is allocated for store } \\
\text { branded products }\end{array}$ & $\begin{array}{l}\text { Not included } \\
\text { in CFA }\end{array}$ & $\begin{array}{c}\text { Not } \\
\text { available }\end{array}$ & $\begin{array}{c}\text { Not } \\
\text { available }\end{array}$ & $\begin{array}{l}\text { Not } \\
\text { available }\end{array}$ \\
\hline
\end{tabular}

\section{Validity and Reliability of Measures}

Confirmatory factor analysis (CFA) was carried out using the maximum likelihood estimation techniques to assess the multiple-item measures on validity and reliability. The single item factor "shelf space" was not added to the measurement model. CFA resulted an acceptable fit for the measurement model but one item measuring SB purchase intention had a very poor loading estimate. After the elimination of this problematic item CFA was run again. Although the chi-square statistic was significant, fit indices provided evidence of an acceptable fit between measurement model and the data: $\mathrm{c}^{2} /$ $\mathrm{df}=2.25$, Goodness-of-fit index $(\mathrm{GFI})=0.91$, Normed-fit-index $(\mathrm{NFI})=0.93$, Comparative-fit-index $(\mathrm{CFI})=0.92$. Furthermore, Root Mean Square Error of Approximation (RMSEA) was large (0.085) but fairly below unacceptable level indicated by Schermelleh-Engel et al. (2003).

To assess the reliability of measures, Cronbach's alpha coefficient, composite reliability scores and average variance extracted were calculated and displayed in Table II. Measures showed acceptable levels of reliability according to critical levels suggested by Fornell and Larcker (1981) and Nunnaly (1978). Factor loadings of individual items to respective latent constructs were shown in Table II which were all large and significant $(\mathrm{p}<0.01)$ providing evidence for convergent validity. Also shared variance between pairs of latent factors in the structural measurement model was compared with average variance extracted that was calculated for each component of pairs to evaluate the discriminant validity (Fornell and Larcker, 1981). It was found that average variance extracted was greater, providing evidence for discriminant validity. Inter-correlations among variables are represented in Table III with the means, standard deviations (SD). 
Table III. Mean, Standard Deviations, and Pearson Correlation Coefficients

\begin{tabular}{lcccccc}
\hline \multicolumn{5}{c}{ Std. } \\
& Mean & Deviation & 1 & 2 & 3 & 4 \\
\hline 1- SB Purchase Intention & 2.2209 & .92019 & & & \\
2- Risk Of Using SB & 2.8289 & 1.01397 & $-.287\left(^{* *}\right)$ & & & \\
3- SB Quality & 2.4487 & .85197 & $.534\left(^{* *}\right)$ & -.107 & & \\
4- SB Familiarity & 1.8837 & .83871 & $.562\left(^{* *}\right)$ & -.143 & $.564\left(^{* *}\right)$ & $.294\left(^{* *}\right)$ \\
5- Shelf Space & 2.80 & .869 & $.246\left(^{* *}\right)$ & .143 & $.478(* *)$ &
\end{tabular}

\section{ANALYSIS AND RESULTS}

After the assessment of measurement model, the hypothesized structural model was tested using the maximum likelihood method in AMOS 7. Analysis results revealed that goodness of fit statistics were in the satisfactory levels $(\mathrm{GFI}=0.94, \mathrm{NFI}=0.94, \mathrm{CFI}=0.97, \mathrm{RMSEA}=0.07)$ supporting the overall fit of proposed model to our data, although the chi-square statistic was $\mathrm{c}^{2}{ }_{(35)}=66.788 \mathrm{p}<0,01$. The estimated path coefficients were presented in Table IV.

Analysis results showed that seven of the ten hypotheses were supported. Purchase intention were found to be significantly affected by perceived risk of using SB $(-.24, \mathrm{p}<0.01)$, perceived quality of SB $(.40, \mathrm{p}<0.01)$ and familiarity $(.45, \mathrm{p}<0.01)$ supporting $H 1, H 2, H 4$. It was found that perceived range of SB shelf space didn't have significant direct effect on purchase intention, so there was no support for $H 7$. Shelf space perception was found to be have an indirectly influence on SB purchase intention by promoting its two antecedents since $H 8, H 10$ were confirmed. It can be concluded that SB shelf space perception contributes significantly to SB familiarity $(0.26, p<0.01)$ and perceived quality $(0.38, \mathrm{p}<0.01)$. Although a significant effect of shelf space was observed on perceived risk of using SB, it is on opposite direction than that suggested $(0.25, \mathrm{p}<0.01)$ so $\mathrm{H} 9$ was not supported. Perceived risk was also proposed to be predicted by familiarity and quality. While $H 3$ was not confirmed since relationship between quality and perceived risk was not significant, familiarity were found to be significantly effective on risk of using SB $(-0.16, \mathrm{p}<0.01)$ supporting $H 5$. Familiarity was also found to be a significant indicator of perceived SB quality $(0.45, \mathrm{p}<0.01)$ and $H 6$ was supported.

\section{Table IV The Standardized Path Estimates and Fit Statistics}

\begin{tabular}{|c|c|c|c|c|c|c|}
\hline & \multicolumn{2}{|c|}{ Hypothesized paths } & \multirow{2}{*}{$\begin{array}{c}\text { Estimate } \\
-.24^{* *}\end{array}$} & \multirow{2}{*}{$\begin{array}{l}\text { S.E. } \\
.06\end{array}$} & \multirow{2}{*}{$\begin{array}{l}\text { C.R. } \\
-3.16\end{array}$} & \multirow{2}{*}{$\begin{array}{c}\text { Results } \\
\text { Supported }\end{array}$} \\
\hline$H 1:$ & Perceived risk of using SB & $\rightarrow$ SB purchase intention & & & & \\
\hline H2: & Perceived quality of SB & $\rightarrow$ SB purchase intention & $.40^{* *}$ & .09 & 3.84 & Supported \\
\hline H3: & Perceived quality of SB & $\rightarrow$ Perceived risk of using SB & -.15 & .13 & -1.39 & Not supported \\
\hline H4: & SB familiarity & $\rightarrow$ SB purchase intention & $.45^{* *}$ & .08 & 4.48 & Supported \\
\hline H5: & SB familiarity & $\rightarrow$ Perceived risk of using SB & $-.16^{* * *}$ & .11 & -1.57 & Supported \\
\hline H6: & SB familiarity & $\rightarrow$ Perceived quality of SB & $.45^{* *}$ & .07 & 5.72 & Supported \\
\hline$H 7:$ & Perceived range of SB shelf space & $\rightarrow$ SB purchase intention & .01 & .07 & .10 & Not Supported \\
\hline H8: & Perceived range of SB shelf space & $\rightarrow$ SB familiarity & $26^{* *}$ & .08 & 3.21 & Supported \\
\hline H9: & Perceived range of SB shelf space & $\rightarrow$ Perceived risk of using SB & $.25^{* *}$ & .10 & 2.82 & Not Supported \\
\hline H10: & Perceived range of SB shelf space & $\rightarrow$ Perceived quality of SB & $.38^{* *}$ & .06 & 5.55 & Supported \\
\hline
\end{tabular}

Chi-square $=66.788$

Degrees of freedom $=35$

Probability level $=0.001$

Goodness of fit index $(\mathrm{GFI})=.94$

Normed fit index $(\mathrm{NFI})=.94$

Comparative fit index $($ CFI $)=.97$

Root mean square error of approximation ( RMSEA ) $=.07$

${ }^{*} \mathrm{p}<0.05 \quad * * \mathrm{p}<0.01$ 


\section{CONCLUSIONS AND RECOMMENDATIONS}

This study investigates the integrative effects of perceived quality, perceived risk, familiarity and shelf space allocation on store brand purchase intention to provide an extensive knowledge regarding factors on which retailers should focus to obtain the strategic competitive advantages of SBs. The results revealed that a very substantial portion of the variance in SB purchase intention (69\%) was explained with the proposed relationships. Supporting previous research, results show that perceived quality, risk and familiarity has a direct effect on SB purchase intention while amount of SB shelf space was indirectly effective. Consistent with the findings from literature, perceived quality and risk appeared as an important indicator of SB purchase intention. The mean value of perceived quality shows that SBs are perceived as having a moderate quality level. As recommended in literature (e. g. Bao et al. 2011), to increase sales of private brands, retailers should put more emphasis on quality image as opposed to positioning on low price. More importantly, retailer should make consumer rely less on extrinsic cues such as price, brand, packaging when assessing store branded products. Dick et al. (1996) found that store brand prone consumers are those who relies significantly less on extrinsic cues. Consistently, familiarity draws attention as a very active antecedent of perceived quality. Accordingly, it is clear that retailer must inform consumer about the SB products. As suggested by Sprott and Shimp (2004), providing additional information by in store sampling is a low cost means of enhancing perceived quality of SB. Researchers argue that when consumers have an opportunity to try a SB they gain knowledge about the intrinsic nature so quality perception is positively effected by this additional information.

As expected, perceived risk, one of the well known antecedents of SB proneness, has a negative influence on SB purchase intention. However, contrary to some earlier findings, quality did not have a significant reducing effect on perceived risk. It can be concluded that consumers are concerned with the risk of using SBs and that it not enough to create a high quality image to reduce the risk. Results reveal that familiarity somewhat decrease the perceived risk of using SB. To this respect, retailer may overcome high-risk challenge by providing information about the brand (Bettman, 1973), by organizing in store taste tests, conducting the benchmark studies and publicize the results on product packaging, in store information boards and through public relations campaigns (Dick et al., 1995). But it must be noted that there is still a big portion of variance in risk that couldn't be explained since predictors of risk explain only $8 \%$ of its variance.

One of the major findings of this research is that familiarity plays the most important role in promoting consumers' purchase intention. Besides its large direct influence on purchase intention it was also found to be effective on risk of using store brand and perceived quality, which were widely studied as main predictors of SB evaluation. It can be concluded that a high level of consumer familiarity is required for increased SB success. Results show that mean value for familiarity is notably low $(M=$ 1.8837). The main implication of this result is that retailers should focus their efforts on increasing the familiarity of their SBs. Dick et al. (1995) suggest to increase familiarity by strengthening the advertising and promotional campaigns, using in-store display, informational material at the point of purchase, product aisles and offering sample products inside the store. Retailer may also use coupons, price deals and other promotions to encourage the trial of their store brand (Sprott and Shimp, 2004).

The results also provide some useful insights for retailers regarding effects of SBs shelf space allocation decisions on consumer perceptions. It seems that there are advantages and disadvantages of extending SB shelf space. Although there was no significant direct link between shelf space and purchase intention, it was found to increase familiarity, perceived quality in favor of purchase intention. On the other side, contrary to expectations, shelf space has a enhancing impact on the perceived risk of using SB. That is, the wider shelf space, the more risky to use SBs. One of the possible explanations for this result is consumers' concern about the social disapproval of using SBs since the SB purchase become more visible as the shelf space of SBs get wider. However, research on exploring the determining factors of risk perception needs to be undertaken before relationship between shelf pace allocation and risk is more clearly understood. Further studies taking perceived risk as a multi dimensional construct need to be undertaken for more clear knowledge about dynamics of risk perception which will also help retailer to reduce overall risk of using SBs. Further works are also needed to avoid some limitation that current study has due to relatively small and homogenous sample. 
Journal of Global Strategic Management | V. 5 | N. 2 | 2011-December | isma.info | 113-123 | DOI: 10.20460/JGSM.2011515802

\section{APPENDIX}

\begin{tabular}{|c|c|c|c|c|c|}
\hline & Percent & & Percent & & Percent \\
\hline GENDER & & & & MONTHL HOUSEHOLD & \\
\hline Male & 48 & Female & 52 & INCOME & \\
\hline AGE & & HOUSEHOLD & & $\begin{array}{l}\text { Less than } 1000 \mathrm{TL} \\
1001-3000 \mathrm{TL}\end{array}$ & $\begin{array}{r}1.8 \\
33.3\end{array}$ \\
\hline From 22-32 & 61.4 & $1-2$ & 22.5 & $3001-5000 \mathrm{TL}$ & 42.9 \\
\hline From 33-42 & 31.6 & $3-4$ & 53.7 & $5001-$ & 14.3 \\
\hline From $43-52$ & 5.1 & $5-6$ & 15 & $000 \mathrm{TL}$ & 6.0 \\
\hline From-53-62 & 1.9 & 7 and more & 0.6 & More than $10.000 \mathrm{TL}$ & 1.8 \\
\hline
\end{tabular}




\section{REFERENCES}

Aaker, D. A. (1991) Managing Brand Equity: Capitalizing on the Value of a Brand Name, The Free Press

Ailawadi, K. L., Neslin , S. A. and Gedenk, K. (2001) "Pursuing the Value-Conscious Consumer: Store Brands Versus National Brand Promotions", Journal of Marketing, 65:71-89.

Ailawadi, K. L., Pauwels, K., Steenkamp, J. E. M. (2008) "Private-Label Use and Store Loyalty", Journal of Marketing, 72:19-30.

Alba, J.W. and Hutchinson, J.W. (1987) "Dimensions of Consumer Expertise", Journal of Consumer Research, 13(4):411-454.

Amrouche, N. and Zaccour, G. (2007) "Shelf-space Allocation of National and Private Brands" European Journal of Operational Research, 180:648-663.

Anselmsson, J. and Johansson, U. (2009) "Third Generation of Retailer Brands - Retailer Expectations and Consumer Response" British Food Journal, 111(7):717-734.

Baker, W. Hutchinson, J. W., Moore, D. and Nedungadi, P. (1986), "Brand Familiarity and Advertising: Effects on the Evoked Set and Brand Preference", Advances in Consumer Research, 13:637642.

Baltas, G. (1997) "Determinants of Store Brand Choice: A Behavioral Analysis”, Journal of Product \& Brand Management, 5(6):315-324.

Baltas, G. and Argouslidis, P. C. (2007) "Consumer Characteristics and Demand for Store Brands", International Journal of Retail \& Distribution Management, 35(5):328-341.

Bao, Y., Bao, Y and Sheng, S. (2011) "Motivating Purchase of Private Brands: Effects of Store Image, Product Signatureness, and Quality Variation", Journal of Business Research, 64:220-226.

Batra, R. and Sinha, R. (2000) "Consumer Level Factors Moderating the Success of Private Label Brands”, Journal of Retailing, 76(2): 175-191.

Bauer, R. A., (1960) “Consumer Behavior as Risk Taking”. In: Cox, D.F.(Ed.), "Risk Taking and Information Handling in Consumer Behavior", Harvard University Press, Boston, MA : 23-33.

Bettman, J.R. (1973) "Perceived Risk and Its Components: A Model and Empirical Test", Journal of Marketing Research, 10(2): 184-190.

Bettman, J.R. (1974) "Relationship of Information Processing Attitude Structures to Private Brand Purchasing behavior", Journal of Applied Psychology, 59(1):79-83.

Brown, M. G. and Lee, J. (1996) “Allocation of Shelf Space: A Case Study of Refrigerated Juice Products in Grocery Stores", Agribusiness, 12(2):113-121.

Bruner II, G. C., Hensel, P. J. And James, K., E. (2005) Marketing Scales Handbook, Vol. 4, American Marketing Association, Thomson.

Coe, B. D. (1971) "Private versus National Preference among Lower- And Middle Income Consumers", Journal of Retailing, 47(3):61-72.

Corstjens, M. and Lal, R. (2000), "Building Store Loyalty Through Store Brands", Journal of. Marketing Research, 37(3): 281-291.

Cunningham, I.C.M.; Hardy, A.P. and Imperia, G. (1982) "Generic Brands versus National Brands and Store Brands", Journal of Advertising Research, 22(5):8-25.

Dhar, S. K. and Hoch, S. J. (1997) "Why Store Brand Penetration Varies by Retailer", Marketing Science, 16(3):208-227.

Dick, A.; Jain, A. and Richardson, P. (1996) "How Consumers Evaluate Store Brands”, The Journal of Product and Brand Management, 5(2):19.

Dick, A.; Jain, A. and Richardson, P. (1995) "Correlates of Store Brand Proneness: Some Empirical Observations", The Journal of Product and Brand Management, 4(4):8-15. 
Erdem, T., Zhao, Y. and Valenzuela, A. (2004) "Performance of Store Brands: A CrossCountryAnalysis of Consumer Store -Brand Preferences, Perceptions, and Risk", Journal of Marketing Research, 41:86-100.

Fornell, C. and Larcker, D. F. (1981) "Evaluating Structural Equation Models with Unobservable Variables and Measurement Error", Journal of Marketing Research, 18(1):39-50.

Frank, R.E. and Boyd, H.W. (1965) “Are Private-Brand-Prone Grocery Customers Really Different?”, Journal of Advertising Research, 5(4):27-35.

Gómez, M. and Okazaki, S. (2009) "Estimating Store Brand Shelf Space: A New Framework Using Neural Networks and Partial Least Squares", International Journal of Market Research, 51(2): 243266.

Hoch, S.J. and Banerji, S. (1993) "When do Private Labels Succeed?", Sloan Management Review, 34:57-67.

Kaplan, L.B.; Szybillo, G.J. and Jacoby, J. (1974) "Components of Perceived Risk in Product Purchase: A Cross Validation”, Journal of Applied Psychology, 59:287-291.

Kara, A. Rojas-Mendes, J. I., Kucukemiroglu, O. and Harcar, T. (2009) "Consumer Preference of Store Brands: Role of Prior Experiences and Value Consciousness", Journal of Targeting, Measurement and Analysis for Marketing, 17(2):127-137.

Keller, L.K. (2008) Strategic Brand Management: Building, Measuring and Managing Brand Equity, Third edition. Pearson International Edition: Upper Saddle River, New Jersey.

Kent, R. J. and Allen, C. T. (1994), "Competitive Interference Effects in Consumer Memory for Advertising: The Role of brand Familiarity", Journal of marketing, 58:97-105.

Liljander, V.; Polsa, P. and Riel, A. (2009) "Modeling Consumer Responses to an Apparel Store Brand: Store Image as a Risk Reducer”, Journal of Retailing and Consumer Services, 16:281-290.

Lin, C.; Marshall, D. and Dawson, J. (2009) “Consumer Attitudes towards a European Retailer's Private Brand Food Products: An Integrated Model of Taiwanese Consumers", Journal of Marketing Management, 25(9): 875-891.

Manzur, E.; Olavarrieta, S.; Hidalgo, P.; Farías, P.; Uribe, R. (2009) “Store Brand and National Brand Promotion Attitudes Antecedents" Journal of Business Research, 64:286-291.

Mieres, C.G.; Martín, A.M.D. and Gutierrez, J.A.T.(2006) "Antecedents of the Difference in Perceived Risk between Store Brands and National Brands", European Journal of Marketing, 40:61-82.

Myers, J. G. (1967) "Determinants of Private Brand Attitude”, Journal of Marketing Research, 4(1):73 -81 .

Narasimhan, C. and Wilcox, R.T. (1998) "Private Labels and the Channel Relationship: A CrossCategory Analysis", The Journal of Business, 71(4):573-600.

Nogales, A. F. and Suarez, M. G. (2005) "Shelf Space Management of Private labels: a Case study in Spanish Retailing", Journal of Retailing and Consumer Services, 12:205-216.

Nunnaly, J. C. (1978) Psychometric Theory. (2nd Ed.) McGraw Hill, New York.

Paulwels, K. and Srinivasan, S. (2004) "Who Benefits from Store Brand Entry", Marketing Science, 23(3): 364-390.

Quelch, J.A. and Harding, D. (1996) "Brands versus Private Labels: Fighting to Win", Harvard Business Review, 74(1):99-109.

Richardson, P., Jain, A.K. and Dick, A.S. (1994) "Extrinsic and Intrinsic Cue Effects on Perceptions of Store Brand Quality", Journal of Marketing, 58:28-36.

Richardson, P., Jain, A.K. and Dick, A.S. (1996) "Household store brand proneness: A framework", Journal of Retailing, 72(2):159-185.

Schermelleh-Engel, K.and Muller, H. (2003) "Evaluating the Fit of Structural Equation Models: Tests of Significance and Descriptive Goodness-of-Fit Measures", Methods of Psychological Research

Online 2003, 8(2):23-74. 
Semeijn, J., van Riel, A.C.R. and Ambrosini, A.B. (2004) "Consumer Evaluations of Store Brands: Effects of Store Image and Product Attributes", Journal of Retailing \& Consumer Services, 11(4):247258.

Sprott, D.E. and Shimp, T.A. (2004) "Using Product Sampling to Augment the Perceived Quality of. Store Brands", Journal of Retailing, 80(4): 305-315.

Stone, R. N. and Grønhaug, K. (1993) "Perceived Risk: Further Considerations for the Marketing Discipline", European Journal of Marketing, 27(3): 39 - 50.

Sweeney, J.C., Soutar, G.N. and Johnson, L.W. (1999) "The Role of Perceived Risk in the QualityValue Relationship: A Study in a Retail Environment”, Journal of Retailing, 75(1):77-105.

Yoo, B.; Donthu, N.and Lee, S. (2000) "An Examination of Selected Marketing Mix Elements and Brand Equity”, Academy of Marketing Science, 28(2): 195-212.

http://www.plturkey.org/yazilar.asp?Konu=PrivateLabel. 15.03.2011.

A Global Nielsen consumer report http://tr.nielsen.com/site/documents/

Nielsen_StoreChoice_ValueReport_Dec07.pdf

http://www.ipsos.com.tr/staticfiles/files/Private_Label_2007_Report_ipsos_KMG.pdf 